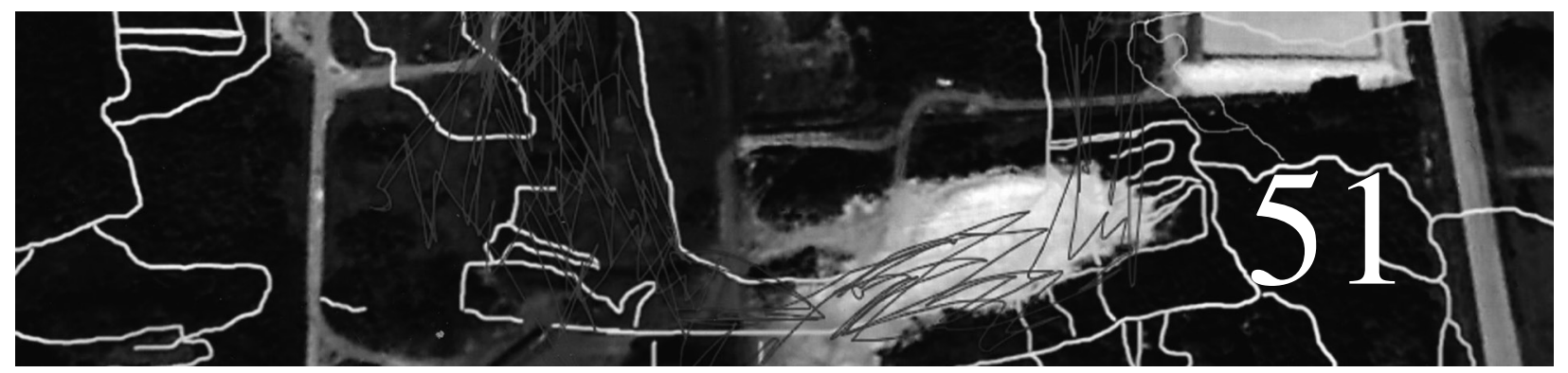

\title{
Transnational Resistance to Communicative Ethnocide: Alevi Television during the State of Emergency in Turkey (2016-18)
}

\author{
Kumru Berfin Emre Cetin
}

\section{INTRODUCTION}

Since the late nineteenth century the media in Turkey has been characterised by state intervention, which has intensified during times of political crisis and upheaval. For this reason, the media has often been in conflict with the state; state officials have censored and attempted to control media content in various ways when it has not complied with official ideology. In the last two decades, state intervention of the media has taken on a transnational aspect: the state has deployed various diplomatic and other strategies, particularly targeted at the Kurdish media, in order to control any alternative discourse on the Kurdish question (Sinclair and Smets, 2014). Following the attempted coup of 15 July 2016, the Turkish government imposed severe restrictions on the media, closing down television channels, imprisoning journalists, and confiscating the property and materials of several media organisations. The operations of the Alevi television channels,
Yol TV and TV10, which broadcast from Germany and Turkey and appeal to the transnational Alevi community living in Europe and Turkey, were also closed down. However, the Alevi television stations turned to alternative means to keep in touch with their audience and found different ways to survive in resistance to the government's measures. Drawing on interviews conducted with television producers and executives in Germany, this chapter focuses on the survival strategies of Alevi television at a time of growing state authoritarianism in Turkey.

The failed coup attempt in July 2016, the latest in a series of military coups (some successful) in Turkey, has challenged and transformed media culture and institutions in various ways. Even though it is a complex transformation, difficult to analyse thoroughly at this current moment, one can draw on certain measures taken against the media as a point of departure for an analysis. At the time of writing this chapter (October 2018), 149 journalists have been arrested ('144 
Gazeteci ve Calisan Cezaevinde', 2018) and over a hundred television stations and newspapers closed down, usually overnight, under decree laws suddenly announced by the government. The attempted coup has resulted in a deep rift between the Gülenist organisation (an Islamic order which has been accused of wishing to achieve political power through infiltrating government organisations; see Tittensor, 2014) and the ruling Justice and Development Party (AKP). However, the government's rapid and brutal response to the coup has reached beyond the Gülenist organisation, which supposedly organised the coup attempt, to target various sections of Turkish society, particularly oppositional groups and communities such as Kurds and Alevis. Located within the Turkish context, the Alevi channels are part of a diverse alternative media environment that has suffered the consequences of the increased authoritarianism that followed the recent coup attempt.

Until 1989 the Turkish media had been monovocal, with only public radio and television available, which were strictly controlled by the state and operated as a means of disseminating and legitimising the state ideology (Adakli, 2009). The introduction of private broadcasting in the 1990s provided relative autonomy from the state's official discourses and cultural policies which allowed popular culture to flourish more 'freely' in the context of media regulation that was now guided by neoliberal economic policies (Adakli, 2009). However, despite a greater integration of Turkish popular culture with the culture of the global media though music video clips and new forms of television entertainment, private radio and television broadcasting could still not transgress the 'red lines' of the official ideology over certain issues, such as the Kurdish question. In that regard, authoritarianism did not arise purely as a result of the attempted coup but has been a characteristic that has defined the Turkish media market, complemented by neoliberal policies, for some time, particularly during the period of the AKP (Yesil, 2016). The coup attempt, however, provided legitimacy for more restrictive measures against the media, which has helped the AKP government to reconsolidate its power in the media sphere.

\section{ALEVI TELEVISION IN THE TRANSNATIONAL CONTEXT}

Alevis are the second largest religious group in Turkey and have suffered persecution on and off since the sixteenth century. Even today they are not recognised in Turkey as a separate religious group despite their ongoing demands to be so (Soekefeld, 2008; White and Jongerden, 2003). For a variety of reasons, including economic and cultural ones, Alevis over the last century left Turkey and migrated to Europe. As a result, vibrant Alevi communities can be found across Europe, with between 400,000 and 600,000 in Germany (Massicard, 2010) and 300,000 in the UK ('Who are we?', 2018). The migration of Alevis to Europe has had significant implications for the emergence and scope of transnational Alevi politics, particularly as it has been a major factor in what has come to be known as the 'Alevi revival' (Soekefeld, 2008). Following the massacre of Alevis in 1993, known as the Sivas Massacre, Alevis mobilised and started to organise as federations in Europe, which has had powerful consequences for Alevis back in Turkey (Massicard, 2012; Soekefeld, 2008; White and Jongerden, 2003). One of the consequences of this mobilisation around Alevi identity has been the emergence of Alevi television and, since the early 2000s, the establishment of various television channels operating via satellite. It is important to note that these types of media outlet reflect the oppositional political spectrum in Turkey rather than simply offering an alternative to the mainstream media. This trend started with MED TV, the first Kurdish television channel, established in 1995, which gave voice to the Partiye Karkeren Kurdistan 
(PKK) at a transnational level (Hassanpour, 1998, 2003).

The Alevi television stations include TV Avrupa (based in Germany), Dem TV (based in the UK), Su TV (based in Germany and later in France), Duzgun TV (based in Germany), Kanal 12 (based in Germany), Cem TV (based in Turkey), Yol TV (based in Germany and later in Turkey), and TV 10 (based in Germany and in Turkey) (Emre Cetin, 2018b). Three of them - Cem TV, TV10, and Yol TV - were on air before the attempted coup in July 2016. After the coup attempt, TV10 was closed down in September 2016 by a decree under the government's state of emergency and Yol TV's broadcasting was suspended in December 2016 by the Radio and Television Supreme Council (RTUK) on the grounds of insulting the President, praising terrorist organisations, and broadcasting without a Turkish license. Cem TV remained in operation from its base in Turkey, while TV10 and Yol TV broadcast on the internet only, mainly from Europe (Emre Cetin, 2018a: 2). Recently, Yol TV came on air through the Astra satellite, and another television station, Can TV, which is the successor of TV10, was established, and broadcast through the Eurosat-Hotbird satellite.

The closure of Yol TV and TV10 led them to seek alternative means to reach their audience. At the same time, while exploring legal options and campaigning against their closure, both television stations continued online streaming through their own websites and made preparations to continue broadcasting in a way which enabled them to minimise state intervention. This chapter focuses on this time period. In this regard, it is important to note that my research on Alevi television is bound by the context of closure and online streaming, which has various implications for production and viewing practices. However, it must be appreciated that although these television stations had to go online, they remained television channels that were using this means of transmission only as a temporary replacement for their suspended services, and they have recently started broadcasting through satellite again.

Currently, Alevi television is situated at the intersection of various media categories which deserve a detailed discussion but which are beyond the scope of this chapter. However, it is useful to briefly point out what these categories are and how Alevi television fits into them. According to Matsaganis, Katz, and Ball-Rokeach, 'Ethnic media are media that are produced by and for (a) immigrants, (b) racial, ethnic, and linguistic minorities, as well as (c) indigenous populations living across different countries' (2011: 6). Therefore, as the media of the ethno-religious and immigrant community of Alevis, Alevi television can be regarded as an ethnic media. However, the way that Alevis have been politicised through their connection to leftist and Kurdish politics in Turkey since the 1970s (Massicard, 2012; Soekefeld, 2008) has led Alevi television to actively engage in broader political issues beyond Alevism. In this regard, Alevi television can be considered as an alternative media as it campaigns for a 'radical social change' that attempts to create a collectivist form of media production in a democratic way (O'Sullivan, 2004: 10). It can also be argued that Alevi television is a form of 'citizen's media' because of its commitment to the values of diversity, leftist understanding and social progress (Rodriguez, 2001, 2011; Waltz, 2005:4).

Both Yol TV (2006) and TV10 (2011) have been based in Germany as well as Turkey. While the executives of TV10 mention that the channel's main office is in Turkey, Yol TV is led from the office in Germany, explained by the fact that Yol TV is owned on behalf of the European Alevi Confederation, whereas TV10 is owned by private individuals. Alevi television stations are transnational, both in the sense that they are based in different countries and have representatives in many others and in the sense that their programme content and audience have a strong transnational dimension which 
cannot be reduced to a simple two-way relationship between Alevis in Germany and Turkey. That is to say, the channels go beyond just helping the diasporic Alevi community keep up with developments in the home country and community (Georgiou, 2001; Matsaganis et al. 2011: 64). They also provide a means to mobilise the Alevi community around Turkish and Alevi politics at a transnational level. The location of these channels, their network coverage (which has also changed as these channels no longer rely on the Turkish satellite Turksat), their programme content, which encompasses a variety of programmes with local, national, and transnational scope, and the relationship between the offices located in Germany and Turkey reflect the complexities of the transnational Alevi network.

While the closure of Alevi television channels is without doubt part of a broader attack on the media and freedom of speech by the Turkish government, given the history of Alevi repression, the blackout of Alevi television can also be seen as part of a policy of communicative ethnocide by the Turkish state. As I argue elsewhere, the silencing of the Alevi media can be regarded as aimed at destroying the communicative means and capacity of the Alevi community, with the ultimate goal of interrupting and eventually annihilating its cultural formation (Emre Cetin, 2018a: 8). Clastres argues that ethnocide is the 'systematic destruction of ways of living and thinking of people from those who lead this venture of destruction' (2010: 103). While genocide persecutes the members of a particular community, ethnocide destroys the culture, aiming to bring about the cultural death of the community. Therefore, communicative ethnocide is not simply about censoring or obstructing the use of media by and for the communities; instead it is part of a sophisticated process of silencing a community and cannot be fully understood without an understanding of the particular history and the context of that community.
I argue that Alevi television has emerged as a resistance to this communicative ethnocide, a resistance that has taken a different direction following the coup attempt, as the Turkish government seeks to advance the measures of ethnocide in the context of the state of emergency. Furthermore, I argue that communicative ethnocide must be regarded as a form of conflict, which is aimed at the elimination of particular groups through the use of different forms of violence, including symbolic violence. Following this point, I suggest that the definition of conflict within the media literature must be expanded to encompass the use of communicative processes, including symbolic destruction, aimed at a community's demise through the destruction of its media, and that community's response to the attempted destruction.

This chapter draws primarily on data gathered from 14 in-depth interviews, which were completed in 2017 with the workers, executives, and producers of Alevi television and are part of a broader project on transnational Alevi citizenship and media. The project focuses on the role of Alevi television in constructing and mobilising Alevi citizenship in a transnational context and more broadly addresses the relationship between old and new forms of media in citizenship practices. The in-depth interviews were transcribed and thematically categorised and then subjected to critical discourse analysis to identify how my interviewees define Alevism and Alevi politics, what they consider the role of Alevi television to be for the Alevi community, and how they see their role in working for Alevi television. In addition, I am currently conducting an ongoing ethnographic study of the Alevi community in London that focuses on Alevi civicparticipation practices and the conceptions of citizenship with reference to the media and Alevi television in particular. For the purpose of this chapter, the primary focus is on the Alevi television workers' accounts of the closures. 


\section{MEDIATISED CONFLICT AND MEDIATISED RESISTANCE}

The literature on media and conflict has largely evolved around considerations of armed conflict, media representations, and the media's role in conflict resolution (Allen and Seaton, 1999; Robinson et al., 2017; Wolfsfled, 1997). This is highly relevant, given the fact that, according to the Institute for Economics and Peace and Global Peace Index, there are conflicts in some form or another in 185 out of 195 countries (Oleyele, 2017: 21). While the mainstream media is a significant point of reference for the general public, ethnic, alternative, and diasporic media also play an important role, especially for the communities who are themselves involved in the conflict, something which is often neglected. As Ogunyemi argues, it is pertinent to understand the role played by the diasporic media 'in escalating or deescalating conflict, their appropriation of journalistic norms, and their engagement with audiences to mediate conflicts' (2017: 1). Despite its importance, the relationship between diasporic and ethnic media and conflict, where communities can develop, disseminate, and even gain acceptance for their perspectives, remains an underresearched area (Keles, 2015; Osman, 2015; Smets, 2016, 2018; Tsavkko Garcia, 2018).

Cottle (2006: 8-9) suggests using the term 'mediatized conflict' in theorising the complexities of the relationship between media and conflict, as it emphasises 'the complex ways in which media are often implicated within conflicts while disseminating ideas and images about them' and stresses the active and performative role of media in enacting, performing, reporting, and representing conflict. The idea of mediatised conflict enables us to see media as a significant actor in producing, reproducing, and dissolving conflict. At this point, it is important to emphasise that the notion of mediatised conflict applies to all sections of the media, including 'nonmainstream' media (no matter whether we call it alternative, diasporic, or ethnic), despite the tendency to confine it to the mainstream, as it plays a key role in mediatising conflict not only by providing alternative representations of the conflict but also by mobilising the audience around certain political options. Again, the Kurdish media and Alevi television exemplify this in the Turkish context. Despite the fact that their influence is limited by the number of their viewers, diasporic, ethnic, and alternative media are still powerful actors in defining the extent of the conflict for their own publics by either escalating or de-escalating its significance. They also draw the boundaries of the discourse of conflict for their viewers, both visually and verbally, by circulating particular images of the conflict, such as massacres and armed conflicts and/or discussing the conflict in particular ways that act as counterdefinitions to those in the mainstream media.

There are various ethnic, religious, and political groups that position themselves in terms of their conflict with those who hold political power and/or there are states and governments who adopt conflict as a policy towards such groups. In the case of the Alevis (and Kurds), conflict - in this case with the state, whether armed or not - has been key for the self-definitions of these communities and cannot be eradicated from their identities in the media. During the current state of emergency, where the government of the ruling AKP has adopted strict measures against oppositional views in the media, this conflict has taken a different turn, and it is this which forms the subject of this chapter. I shall examine the selfperceptions that Alevis have of their identity in relation to their conflict with the state in the context of television and the ways in which they offer resistance through online technologies.

\section{ALEVI TELEVISION AS RESISTANCE}

In this section I shall argue that Alevi television has emerged as a form of resistance against the attempted suppression of Alevi identity by the state and examine how Alevis 
have reconstructed themselves as a 'mediatised community' through television. This resistance is twofold: resistance against mainstream media practices and its representation regime, and resistance against the state's policies towards (against) Alevis. Research on alternative media clearly shows that those who are involved in the production process mostly consider their role in the media to be a form of resistance to the mainstream and a social struggle against it (Peschanski, 2007). They also consider it an alternative field of production (Atton, 2002: 29) despite their limited power in democratising the media environment, and a way of empowering the minority's struggle for recognition (Bailey et al., 2008). Those involved in Alevi television are no exception. Salih is an experienced producer who has been part of TV10 since the beginning. His account not only demonstrates that Alevi media professionals have to render themselves invisible within the mainstream media environment: it also shows that this exclusion has mobilised them to create new means for themselves:

The main reason why we established a television channel is because the mainstream media has turned a blind-eye towards Alevis. They want us to take part, they offered us to go and work with them. They said come and work with us but leave Alevism behind. You come and work but your Alevism can't come. [...]. This is their perspective on Alevis; that's why you look for a channel where you can express yourself. This is the aim of our channels. ${ }^{1}$ (Salih, TV10)

Rather than just being concerned with the misrepresentation of Alevism, Salih complains about the invisibility of Alevis and the lack of an Alevi perspective when Alevi questions are discussed on mainstream television. Salih's account also points to the 'desired' profile required of a media professional from which her/his ethno-religious identity must be eliminated if they wish to be part of the mainstream media system. This denial of the existence of an ethno-religious identity other than that approved by the state indicates how the state's ethnocide policies have repercussions for the media market and its values. According to Taylor, 'Nonrecognition or misrecognition can inflict harm, can be a form of oppression, imprisoning someone in a false, distorted, and reduced mode of being' (1994: 25). In this regard, the attempt by Alevis to express themselves on and through television can be seen as a form of resistance against this form of oppression, framed by the nonrecognition and misrecognition of particular identities. Of course, this is not specific to Alevis but is relevant to other groups who engage their media practices with human rights movements and/or identity politics. However, what marks out Alevi television is its ability to establish connections between the local, national, and transnational, even instantaneously. For instance, Alevi television played a key role in mobilising Alevis in Turkey and Europe during the attacks targeted against Alevi families and individuals living in different parts of Turkey.

Oya, who has been involved in the Germany Alevi Federation for over a decade and has produced and presented different programmes for Yol TV, describes how television has given voice to Alevis and enhanced their resistance to the suppression of their identity. She argues that television is a must for Alevi identity politics:

Of course television is very important. [...] It is crucial for you to express yourself, explain yourself to others and present the problems faced by an oppositional peoples. [...] In order to express these, be the voice of the voiceless, television is very important for us, especially for conveying the achievements of the European Alevis to Turkey... That's why Yol TV is a must for us. Our struggle will continue [against the closure] either through the internet [online streaming] or through other systems. (Oya, Yol TV)

Like many Alevis, Oya considers Alevis as part of oppositional groups in Turkey (that is, in opposition to the group in power) and regards Alevi television as not only the voice of Alevis but also as 'the voice of the voiceless', those who are invisible in the mainstream Turkish media that only echoes the 
policies of the AKP government. In this regard, Alevi television is positioned against the mainstream Turkish media and within the 'other' stream, which resists the mainstream's discourse defined by Turkishness and Sunni Islam. At this point it is important to highlight that this view of Alevi television is shared by the viewers in the UK whom I interviewed and the Alevis with whom I had informal discussions in Turkey, for, despite any criticisms of Alevi television channels, its viewers feel that they are empowered by its existence.

The producers and decision-makers of Alevi television who are individual activists or activists involved in Alevi organisations consider their practices as a form of political activism, which, by creating a 'common sense' - that is, a shared sentiment among Alevis about being Alevi - not only challenges mainstream media practices but also challenges state policies towards Alevis. Halit is a well-known political commentator who has been involved in the Kurdish movement for years. While making a comparison between Kurdish and Alevi movements he argues that:

Television is quite important in terms of nationalisation. ${ }^{2}$ [...] Alevism was more local, so attacks against Alevis and the reactions against those attacks remained local. Even if it was made national, it was made national through Kurdish politics or the left or the Republican People's Party not through Alevi [identity] politics. [...] Rather than Alevis hiding themselves in their localities, they became national. This was a need and television had to reflect it. (Halit, TV10)

According to Halit, Alevi television has served as a significant tool for Alevis, allowing them to express themselves and to be connected, thereby creating a common Alevi identity similar to a national one. Halit's description has many points of resemblance with Anderson's (1991) notion of 'imagined communities', where the print media not only creates a common agenda for those who are bound by the same national boundaries but also a 'common sense'. In the case of an
Alevi 'imagined community', there is no doubt that television has helped to construct an alternative public, but rather than simply being on a national scale it has become a transnational one. Some caution, however, is required not to overstate the role of television in the making of this transnational alternative public of Alevis, since they have been organising in European countries for more than three decades. But television has added the dimension of instantaneity and expanded the vision of connectedness by enabling dynamic links between the local, national, and transnational and by creating a transnational imagination (Emre Cetin, 2018b).

My interviewees also emphasised the role Alevi television broadcasting from Europe has played in Turkey. Despite the fears surrounding the overt expression of Alevi identity in Turkey, the example set by European Alevi organisations as presented through Alevi television, as Oya and Vedat emphasise, has been important in empowering those living in Turkey and has acted as a facilitator in recruiting more Alevis to Alevi organisations. Furthermore, having television channels in which Alevis are in control of the ways in which they are represented, as well as having the ability to address the broader community, has helped them to gain confidence and come forward as Alevis:

First of all television enabled the communication between Alevis in Turkey and Alevis in Europe and to keep up with each other being their voice. Secondly $[. .$.$] the mobilisation we created through$ television when we go to Turkey, when we broadcast the memorial events of the Alevi massacres, encouraged the expansion of Alevi recruitment in Turkey. [...] Alevis living in villages and in cities [in Turkey] gained a self-confidence. (Vedat, Yol TV)

My interviewees' accounts in this chapter demonstrate how the workers on Alevi television channels consider their role as vital to Alevi politics - not only because many actively take part in the Alevi movement but because of their confidence in arguing how this is based on the feedback they receive from their audience. Their hands-on approach 
to television broadcasting enables them to receive face-to-face, lively comments and criticisms from the viewers about the programmes and their approach to Alevi politics. This is also evident in their programmes on Alevi events in Turkey and Europe or those where they visit Alevi villages in Turkey. No doubt, one can also argue that their commitment and idealism may lead them to overestimate the role that they play in Alevi politics as broadcasters; however, the viewers' endorsement of Alevi television and the way the Turkish state seeks to silence these channels suggest the opposite.

\section{DIGITAL RESISTANCE: IPTV AND ONLINE STREAMING}

After the attempted coup, the increasing pressure on those journalists and media professionals targeted by the Turkish government led them to use online services as a means of broadcasting. Currently, social media accounts, live video streaming services such as Periscope, and video ondemand services such as YouTube operate as platforms to reach alternative publics in the suppressed media environment of Turkey. Both Yol TV and TV10 have benefited from broadcasting online after their closure in Turkey. While both of these channels have relied on online streaming, Yol TV has used IPTV $^{3}$ in order to make itself available through smart-television sets and computers. In this regard, the closing of Alevi television channels has resulted in expanding online potential for Alevi broadcasts:

Broadcasting [online streaming] continues thanks to the technical infrastructure we have here in Europe. This is nothing like we had on Turksat [satellite] of course. [...] Currently our programmes are more suited to the logic of online streaming, shorter, less focused, conveying short messages to the society. [...] We have our viewers, we receive feedback and it [streaming] is more or less effective. (Salih, TV10)
However, in the contemporary Turkish context, online streaming does not necessarily mean being more accessible and free from pressure. Even though Salih adopts an optimistic tone with regard to online streaming and the potential for social media, the majority of my interviewees are pessimistic about going online. They emphasise that a big potential has been lost, as they observe their number of viewers dropping significantly after starting online streaming. This is primarily a result of the audience profile for these channels. According to my interviewees who work in Alevi television channels, the average viewer profile of Yol TV and TV10 is a middle-aged Alevi from either an urban or rural backgrounds with limited digital literacy and digital skills. Hence, the average viewer is less able and less willing to follow these channels compared to the situation before their closure.

Despite these limitations, it is important to acknowledge the transnational character of this online resistance. As one interviewee states, online streaming is possible thanks to the infrastructure and human resources available in Germany. Recently, a new channel, Can TV, which can be regarded as the successor of TV10, has been established, again in Germany. This demonstrates that the Alevi media is responding at a transnational level to the pressures originating from the national context. Since the goods and materials owned by TV10 in Turkey have been confiscated by the government under the state-ofemergency law, TV10 has had to rely solely on its resources in Germany. Thus, resistance is not only taking place at the symbolic level but also at the economic one, and those Alevi channels that still have resources in Turkey have to be very careful to preserve and use them. These television channels do not rely solely on digital media for survival: they employ various strategies that include transferring human resources in Turkey for use on documentary projects on Alevism (TV10), seeking alternatives to the Turksat satellite, which is controlled by Turkey (Yol TV), 
and campaigning for their right to broadcast (Emre Cetin, 2018a). Nevertheless, online streaming and IPTV have been crucial in maintaining audience engagement (albeit at a reduced level) as well as demonstrating that Alevi channels are committed to the 'Alevi cause' despite the pressures. That is why currently Alevi television operates as an important tool for the resistance of Alevis.

\section{CONCLUSION}

Despite the growing emphases on online diasporic communities, my research demonstrates that television is still a significant medium for transnational communities who struggle for political and cultural recognition. The cases of Yol TV and TV10 indicate certain strategies employed by broadcasters, such as switching to online streaming and IPTV, despite the drop in the audience interest and engagement. These cases also confirm that it is more difficult for the political authorities to control online streaming than satellite broadcasting, which allows communities to employ their digital resources as a counter-strategy during times of authoritarianism and increasing oppression. However, the fruitfulness of this strategy is highly disputed, since having digital resources does not eliminate existing digital inequalities and access to internet and digital literacy. In this regard, online streaming is far from being a long-term solution for digitally marginalised communities such as Alevis. Furthermore, the digital sphere is not free from political pressure. At the time of writing this chapter, the Turkish government has introduced measures to exert a broader control of the internet, and the Turkish Parliament has recently passed a bill allowing the radio and television regulator, RTUK, to control online streaming content.

In this chapter, I have demonstrated that Alevi television cannot be compartmentalised into the category of diasporic media: it articulates the complexities of transnational networks and reconstructs them in particular ways despite the challenges posed by the Turkish national political agenda. The Alevi case indicates that television is still an important tool of resistance for marginalised communities against state oppression. It also emphasises the necessity of situating the relationship between traditional and digital media in a complex media ecology where transnational communities turn towards different media and different uses. The closure of the Alevi television channels and their re-opening through different satellites, which redefines their geographical scope, demonstrates the powerful influence of the national context in the home country on the transnational community's communicative practices. $^{4}$

\section{Notes}

1 All interviews were conducted in Turkish and the quotes have been translated by the author.

2 The interviewee here is referring to the idea that Alevis start to feel connected at the national level rather being isolated in their own localities.

3 Internet Protocol Television (IPTV) is the streaming of television content online, enabling viewers to watch television content either on their sets or on their computers immediately.

4 Further analysis of the ethnographic data and the yet to be analysed audience data will shed further light on the different generational media practices and their implications for resistance and identity politics.

\section{REFERENCES}

144 Gazeteci ve Calisan Cezaevinde. (20 April 2018). Retrieved from https://tgs.org.tr/ cezaevindeki-gazeteciler/

Adakli, G. (2009). The process of neoliberalization and the transformation of the Turkish media sector in the context of the new media architecture. In J. Harrison and B. Wessels (Eds) Mediating Europe: New media, mass communications, and the 
European public sphere (pp. 286-318). Oxford: Berghan Books.

Allen, T. and Seaton, J. (1999). The media of conflict: War reporting and representations of ethnic violence. London: Zed Books.

Anderson, B. (1991). Imagined communities: Reflections on the spread of nationalisms. London: Verso.

Atton, C. (2002). Alternative media. London: Sage.

Bailey, O.G., Cammaerts, B., and Carpentier, N. (2008). Understanding alternative media. Maidenhead: Open University Press.

Clastres P. (2010). Archeology of violence. Los Angeles: Semiotext(e).

Cottle, S. (2006). Mediatized conflict: Developments in media and conflict studies. Maidenhead: Open University Press.

Emre Cetin, K. B. (2018a). Communicative ethnocide and Alevi television in the Turkish context. Media, Culture and Society, 40:7, 1008-1023,DOI: 10.1177/0163443718754651.

Emre Cetin, K. B. (2018b) Television and the making of a transnational Alevi identity. National Identities, 20:1, 91-103, DOI: 10.1080/14608944.2016.1247260.

Georgiou, M. (2001). Diaspora, identity and the media: Diasporic transnationalism and mediated spatialities. Cresskill, NJ: Hampton Press.

Hassanpour, A. (1998). Satellite footprints as national borders: Med-tv and the extraterritoriality of state sovereignty. Journal of Muslim Minority Affairs, 18:1, 53-72.

Hassanpour, A. (2003). Diaspora, homeland and communication technologies. In H. K. Karim (Ed.) The Media of Diaspora (pp. 76-88). London: Routledge.

Keles, J. Y. (2015). Media, diaspora and conflict: Nationalism and identity amongst Turkish and Kurdish migrants in Europe. London: I.B. Tauris.

Massicard, E. (2010). Alevi communities in Western Europe: Identity and religious strategies. In J. S. Nielsen (Ed.) Yearbook of Muslims in Europe (pp. 561-592). London: Brill.

Massicard, E. (2012). The Alevis in Turkey and Europe: Identity and managing territorial diversity. London: Routledge.

Matsaganis, M. D., Katz, V. S., and BallRokeach, S. J. (2011). Understanding ethnic media: Producers, consumers, and societies. London: Sage.

Ogunyemi, O. (2017). Communicating conflict from the diaspora. In Media, Diaspora and Conflict (pp. 1-16). Cham: Palgrave Macmillan.

Oleyele, A. (2017). Diaspora, journalism and conflicts in transnational media circuits. In A. Ogunyemi (Ed.) Media, Diaspora and Conflict (pp. 20-36). Cham: Palgrave Macmillan.

Osman, I. (2015). The Somali media, diaspora communities and the concept of conflict re-creation. Journalism, Media and Cultural Studies Journal, 7, 1-14, DOI: http://doi. org/10.18573/j.2015.10006

O'Sullivan, T. (2004). Alternative media. In T. O'Sullivan, J. Hartley, D. Saunders, M. Montgomery, and M. Fiske (Eds.) Key concepts in communication and cultural studies (p. 10). London: Routledge.

Peschanski, J. O. (2007). Communication of the oppressed: Alternative media and their impact in contemporary Latin America. In K. Coyer, T. Dowmunt, and A. Fountain (Eds.) The alternative media handbook (pp. 154-162). London: Routledge.

Robinson, P., Seib, P., and Frohlich, R. (2017). Routledge handbook of media, conflict and security. London: Routledge.

Rodriguez, C. (2001). Fissures in the mediascape: An international study of citizens' media. Cresskill, NJ: Hampton Press.

Rodriguez, C. (2011). Citizens' media against armed conflict: Disrupting violence in Colombia. Minnesota, MN: University of Minnesota Press.

Sinclair, C. and Smets, K. (2014). Media freedoms and covert diplomacy: Turkey challenges Europe over Kurdish broadcasts. Global Media \& Communication, 10:3, 319-331, DOI: https://doi.org/10.1177/ 1742766514552380

Smets, K. (2016). Ethnic media, conflict, and the nation-state: Kurdish broadcasting in Turkey and Europe and mediated nationhood. Media, Culture and Society, DOI: https://doi. org/10.1177/0163443715620928

Smets, K. (2018). Ethnic identity without ethnic media? Diasporic cosmopolitanism, (social) media, and distant conflict among young 
Kurds in London. The International Communication Gazette, 80:7, 603-619, DOI: 10.1177/1748048518802204

Soekefeld, M. (2008). Struggling for recognition: The Alevi movement in Germany and in transnational space. New York: Berghahn Books.

Taylor, C. (1994). The politics of recognition. In A. Gutman (Ed.) Multiculturalism: Examining the politics of recognition (pp. 25-74). Princeton, NJ: Princeton University Press.

Tittensor, D. (2014). The house of service: The Gulen movement and Islam's third way. Oxford: Oxford University Press.

Tsavvko Garcia, R. (2018). Diasporas and the role of social media on militant/political activities: The Basque diaspora in Argentina in the spotlight. Journal of Migration and Culture, 9:1, 77-90, DOl: https://doi. org/10.1386/cjmc.9.1.77_1

Yesil, B. (2016). Media in Turkey: The origins of an authoritarian neoliberal state. Chicago: University of Illinois Press.

Waltz, M. (2005). Alternative and activist media. Edinburgh: Edinburgh University Press.

White, P. and Jongerden, J. (2003). Turkey's Alevi enigma: A comprehensive overview. Boston: Brill.

Who are we? (20 April 2018). Retrieved from http:// www.alevinet.org/SAP.aspx?pid=About_en-GB

Wolfsfled, G. (1997). Media and political conflict: News from the Middle East. Cambridge: Cambridge University Press. 